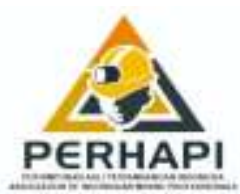

INDONESIAN MINING PROFESSIONALS JOURNAL

PERHAPI, Komplek Rukan Crown Palace Blok D. 09

II. Prof. Dr. Soepomo, SH No. 231, Tebet - Jakarta Selatan 12870

Telp : 021-83783766. Email : jurnol.perhopi@gmai.com

https://jumal.perhapl.or.id/index.php/impj

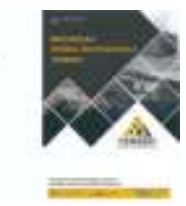

\title{
PURCHASING STRATEGIES IN THE KRALJIC PORTFOLIO MATRIX - A CASE STUDY IN OPEN PIT COAL MINING
}

\author{
Alim Perdana1) dan Nur Budi Mulyono²) \\ 1) PT Kaltim Prima Coal, \\ 2) School of Business Management, Bandung Institute of Technology,
}

Artikel masuk : 30-04-2021, Artikel diterima : 25-06-2021

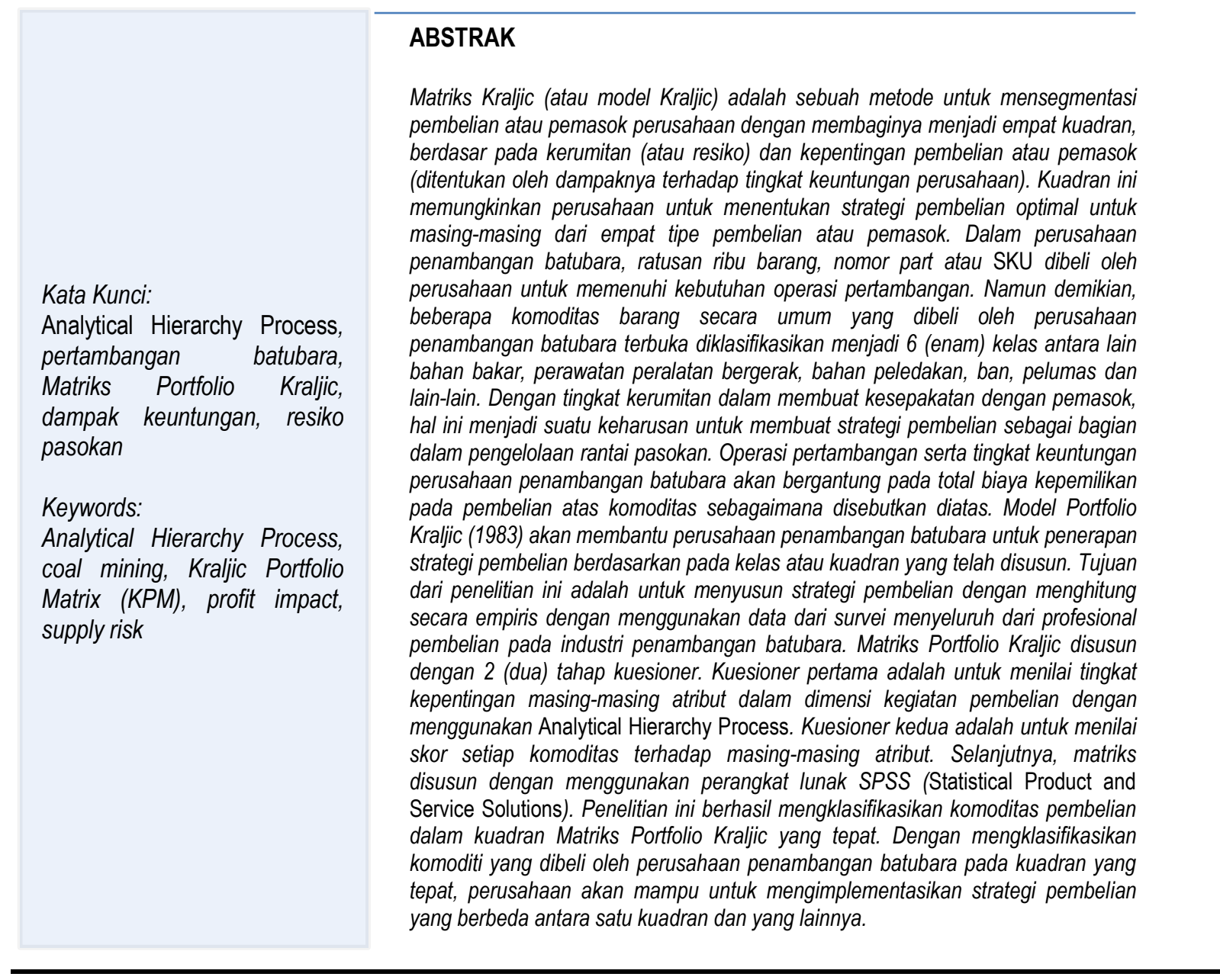

*Penulis Koresponden: Alim.Perdana@kpc.co.id_

Doi : https://doi.org/10.36986/impj.v3i1.41 


\section{ABSTRACT}

Kraljic matrix (or Kraljic model) is a method used to segment the purchases or suppliers of a company by dividing them into four quadrants, based on the complexity (or risk) of the supply market (such as monopoly situations, barriers to entry, technological innovation) and the importance of the purchases or suppliers (determined by the impact that they have on the profitability of the company). This quadrant allows the company to define the optimal purchasing strategies for each of the four types of purchases or suppliers. In coal mining company, hundred thousand goods, part number or SKUs are purchased by corporate in fulfilling its mining operations requirement. However, the commodities generally purchased by open pit coal mining company are classified into 6 (six) classes which are fuel, maintenance of mobile equipment, blasting material, tyre, lubricants, and others. With the complexity of dealing with suppliers, it is mandatory for developing purchasing strategies as part of managing of supply chain. Mining operations and profitability of coal mining company shall depend on the total cost of ownership in purchasing the abovementioned commodities. This Kraljic Portfolio Model (1983) will assist coal mining company in applying purchasing strategies based on the class or quadrant which has been developed. Objective of this research is to develop purchasing strategies by empirically quantifying using data from a comprehensive survey among purchasing professionals in coal mining industry. Kraljic Portfolio Matrix is developed with 2 (two) stages of questioner. First questioner is to assess the importance level of each attribute in the dimension of purchasing activity by using Analytical Hierarchy Process. Second questioner is to assess every commodity's scoring against each supply attribute. Subsequently, the matrix is developed by using SPSS (Statistical Product and Service Solutions) software. This research successfully classifies purchasing commodity in the appropriate quadrant of Kraljic Portfolio Matrix. By classifying the commodities purchased by coal mining company in the right quadrant of Kraljic Portfolio Matrix, the company will be able to implement the right purchasing strategies which will be different in one quadrant and another.

\section{INTRODUCTION}

\section{BACKGROUND}

The procurement portfolio model has received a lot of attention in the recent literature on professional procurement. Kraljic (1983) has introduced one of the most recognized portfolio models. His model has had a siginificant influence on professional purchasing (see the evidence of Kamann and Bakker, 2004; Gelderman, 2003). It also inspired many academic authors to undertake further stuudy into portfolio models (e.g. Gelderman and Van Weele, 2002, 2003, 2005; Dubois and Pedersen, 2002; Zolkiewski and Turnbull, 2002; Nellore and Soderquist, 2000; Wynstra and ten Pierick, 2000; Croom, 2000; Bensaou, 1999; Lilliecreutz and Ydreskog, 1999; Olsen and Ellram, 1997; Wagner and Johnson, 2004; Dyer et al., 1998).

According to Kraljic (1983) a company's supply strategy depends on two factors: (1) profit impact and (2) supply risk. Other scholars introduced variations of the original Kraljic matrix (e.g. Elliott-Shircore and Steele, 1985; Syson, 1992; Hadeler and Evans, 1994; Olsen and Ellram, 1997). The proposed matrices are very similar to the Kraljic matrix in that they took comparable dimensions, and derive equivalent recommendations. Usually these matrices only provide one recommendation for each portfolio quadrant, namely: form partnerships for strategic products; assure supply for bottleneck products; exploit power for leverage products and ensure efficient processing for non-critical products, but in a recent study of the actual usage of matrices by professional buyers pointed out that buyers clearly distinguish several strategies within each quadrant (Gelderman and Van Weele, 2003). In this regard, buyers have identified two strategies: (1) strategies to hold their position in the quadrant and (2) strategies to move to another position.

Kraljic (1983, p. 112) stipulated that the general idea of the portfolio methodology is to "minimize supply weakness and maximize potential buying bargain". Likely, power and dependence have to be the main roles in the Kraljic approach. Relative power and dependence position of buyers and suppliers are expected to be the importance factors in explaining the circumstances which influence the option of purchasing strategy within each quadrant.

\section{OBJECTIVE}

The researchers have observed literatures regarding mining industry in many sources. Most of studies in mining industry observe implementation in mining operations such as rock mining, blasting, slope stability, geology, etc. While there is no study observes related to purchasing strategy in purchasing the commodity required for mining operations, specifically with Kraljic Portfolio Matrix theory.

The goal of this paper is to establish Kraljic Portfolio Matrix which will be developed for implementation in coal mining company. This will be done with respect to the purchasing strategies in each quadrant of the Kraljic purchasing portfolio matrix of commodities purchased for coal mining operations. In order to do this, the researchers have defined the concepts of power and dependence in terms of buyer's and supplier's dependence. Subsequently, the researchers have developed "constructs" (?) for buyer's dependence as well as supplier's dependence. The researchers' 
empirical analysis for supply risk is founded on a survey among 11 purchasing professionals in a world class coal mining company. On the basis of the survey data, the researchers have assessed power and interdependence in buyer-supplier relationships. While for profit risk, the researchers utilized actual spending of the company in the last five years for period of 2015 to 2019. Generally this study will contribute for enriching understanding of the (perceived) power and interdependence in buyersupplier relationships for implementation to open pit coal mining company.

This journal's structures consist of introduction, literature review and business overview, methodology, result and analysis, discussion, and conclusion.

\section{LITERATURE REVIEW AND BUSINESS OVERVIEW}

\section{The Kraljic purchasing portfolio matrix}

In supply chain management, the Kraljic portfolio matrix is a method used to classify a company's procurement or suppliers into four categories based on the complexity (or risk) of the supply market (such as monopoly, entry barriers, technological innovation), and the procurement or supplier's Importance (depending on their impact on the company's profitability).

Kraljic (1983) proposed a four-stage approach $k$ for formulating a supply strategy for a single product or product groupas a framewor. In the first stage, the company categorizes all products it purchases based on profit impact and supply risk. Then, the company weighs the bargaining power of its suppliers and its own capabilities. Subsequently, the company positions the products determined in the first phase as strategic products in the portfolio matrix (high profit impact and high supply risk). Finally, it formulates procurement strategies and action plans for these strategic products based on its own strength and the strength of the supply market.

Mining industry generally or coal mining industry specifically is a high investment industry as it requires hundred million United States Dollars investment in operating its mining activity, depends on the production level, Stripping Ratio and mining distance. While the transaction value of coal mining company is very high, purchasing professional in this company has to purchase hundred thousand SKUs from hundred or thousand suppliers in fulfilling its operational demand. Hence, it is mandatory for coal mining company to implement right purchasing strategies in Purchasing Department's dayto-day activity.

With the assistance from this matrix, professional buyers in coal mining company can differentiate between various supplier relations and consider best strategies which will be appropriate for each category and therefore they will effectively manage suppliers (Nellore and Soderquist, 2000).

Table 1. The Kraljic purchasing portfolio model (modified from Kraljic, 1983, p. 111)

\begin{tabular}{|c|l|l|}
\hline \multirow{2}{*}{ Profit Impact } & \multicolumn{2}{|c|}{ Supply Risk } \\
\cline { 2 - 3 } & \multicolumn{1}{c|}{ Low } & \multicolumn{1}{c|}{ High } \\
\hline \multirow{2}{*}{ High } & Leverage items & Strategic items \\
& Exploit purchasing power & Form partnerships \\
\multirow{2}{*}{ Low } & Non-critical items & Bottleneck items \\
& Ensure efficient processing & Assure supply \\
\hline
\end{tabular}

A recent study by Gelderman and Van Weele (2003) put an attention to the professional purchasers' experience with the implementation of the portfolio matrix in their daily jobs. Figure 1 provides an overview of strategic directions for all categories. 


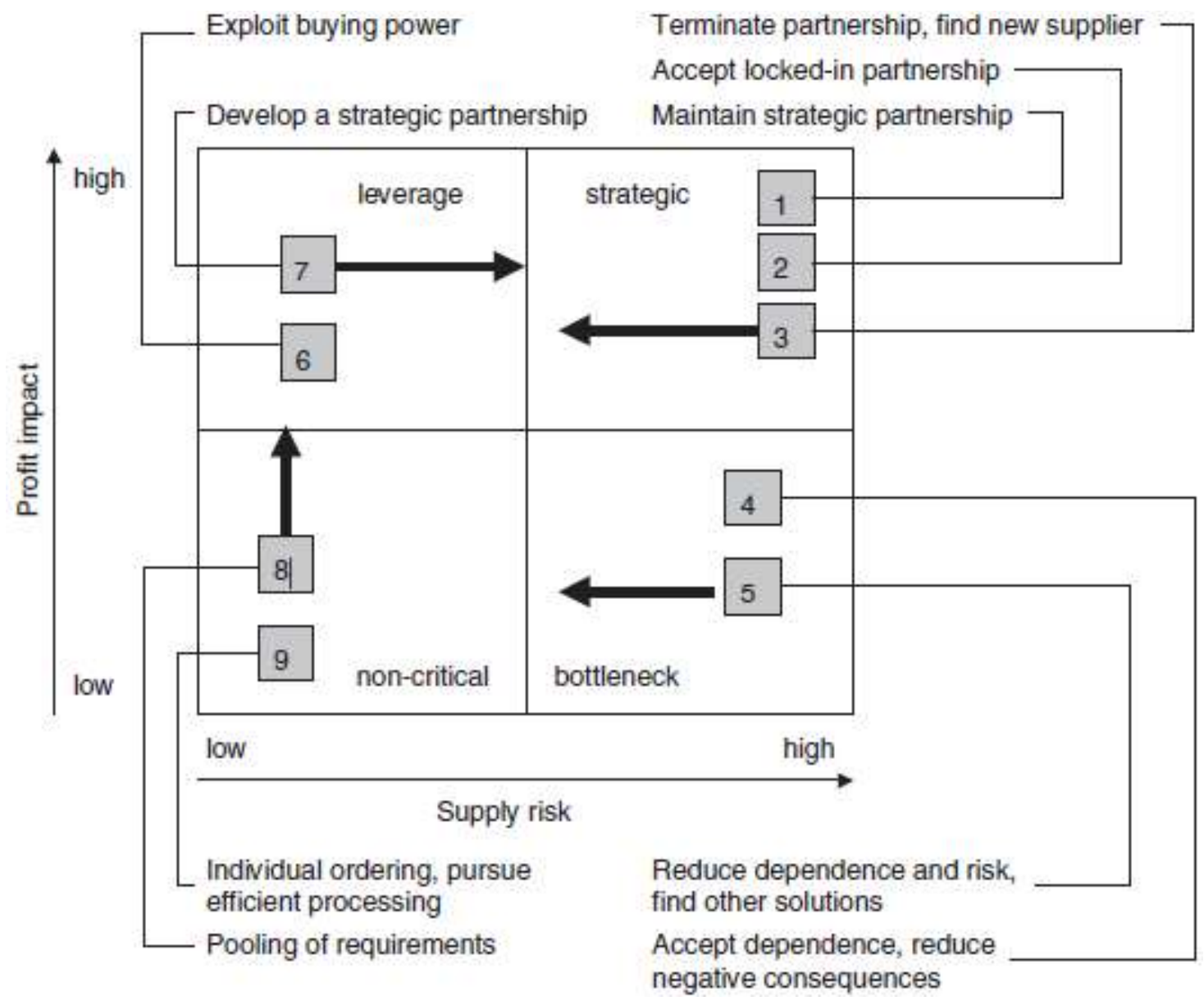

Figure 1. Overview of purchasing strategies for all portfolio quadrants (modified from Gelderman and Van Weele, 2003, p. 212).

Several studies for implementation of Kraljic Portfolio Matrix (1983) have been implemented in many industries, popularly in manufacturing and construction companies and their downstream supply chain process. However recently there is no study empirically researches implementation of purchasing strategy with basis of Kraljic Portfolio Matrix theory in mining industry, moreover if the matrix is established with quantitative data.

\section{Analytic Hierarchy Process (AHP)}

Analytic Hierarchy Process (AHP), which has been introduced by Thomas L. Satty (1980), has become the most effective tool for dealing with complex decision making. This theory can be implemented on the premises for the case that any decision making problem can be decomposed in to multi-level hierarchical structure which consist of goal, criteria and alternatives.

AHP is used to derive ratio scales from discrete and continuous paired comparisons in a multi-level hierarchical structure. This comparison can be obtained from actual measurements or from a fundamental scale that reflects the relative strengths of various preferences and feelings. With a hierarchy, a complex problem can be broken down into groups which are then arranged into a hierarchical form so that the problem will appear more structured and systematic (Saaty and Vargas, 1994). 


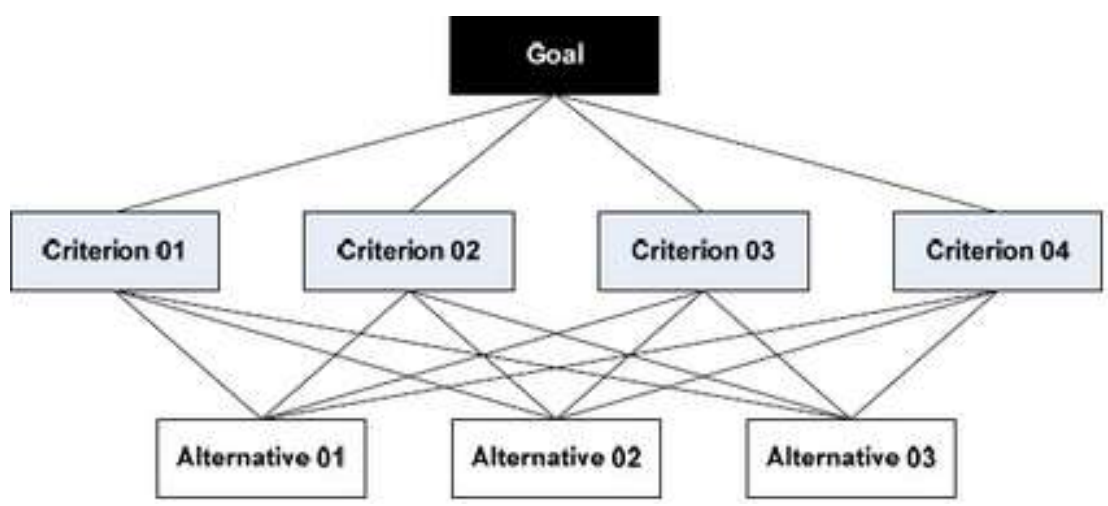

Figure 2. Overview of Analytic Hierarchy Process (AHP) (established by Saaty, 1980).

From hundred thousand SKUs which coal mining company has to purchase in fulfilling its mining operations demand, professional purchasers have to deal in its best cost to his/her company. Purchasers will have to face that there are many considerations in making decisions such as number of available suppliers and the alternate supplier, product performance, handling and storing of the product, product substitution, etc. Other than abovementioned criteria, professional purchasers must have good understanding the product which will be purchased in term of supply risk in the market.

The researchers are assisted by AHP in developing Kraljic Portfolio Matrix by deciding weighing in term of Market Risk, Performance Risk and Complexity Risk. Furthermore, AHP also assists to establish the index of each purchase commodity.

\section{Open Pit Coal Mining Business Overview}

Coal has an important role in global energy demand, especially in terms of power plant and industrialization (smelter); and energy security. Along the time, usage of coal continuously increase and will continue, in line with the usage increase of other fuels to support world economic and social development, especially for aggressive developing countries such as in China and India.

According to "The Global Value of Coal" published published on www.carbontracker.org in 2012 entitled International Energy Agency, coal has difference with other energt sources, as the following.

1. Abundance and accessibility: Coal is the most common fossil fuel and has been massively distribute over the world. Coal now has been used as many as $64 \%$ of the recoverable fossil resources, while oil and natural gas are only around $19 \%$ and $17 \%$. The proven coal reserves of coal is expected to be more than one trillion tons. Coal has been distributed in all region of the world. The Western Hemisphere itself has more than 300 billion tonnes of coal, Europe has 73 billion and Australia has over 75 billion;

2. Secure energy: Coal reserves are widely distributed around the world. This global distribution provides energy security across brand political arenas;

3. Reliability: The abundance and logistics of coal, coupled with its relatively low and stable pricing, laid the foundation for reliable energy supply. The characteristis of coal make it a very attractive base load fuel. Consistently, compared to other fuels, coal power generated significantly exceeds the relative capacity of coal;

4. Affordability: According to analysis of International Energy Agency (IEA) on electricity's average costs, supercritical plants are one of the most reasonable sources of power generation in China, costing US\$ 33/Mega Watt hour compared with hydro at US\$50, nuclear at US\$ 53 and wind at US\$ 71 (IEA, 2010).

The mining activities are typically illustrated as shown in Figure 3. 


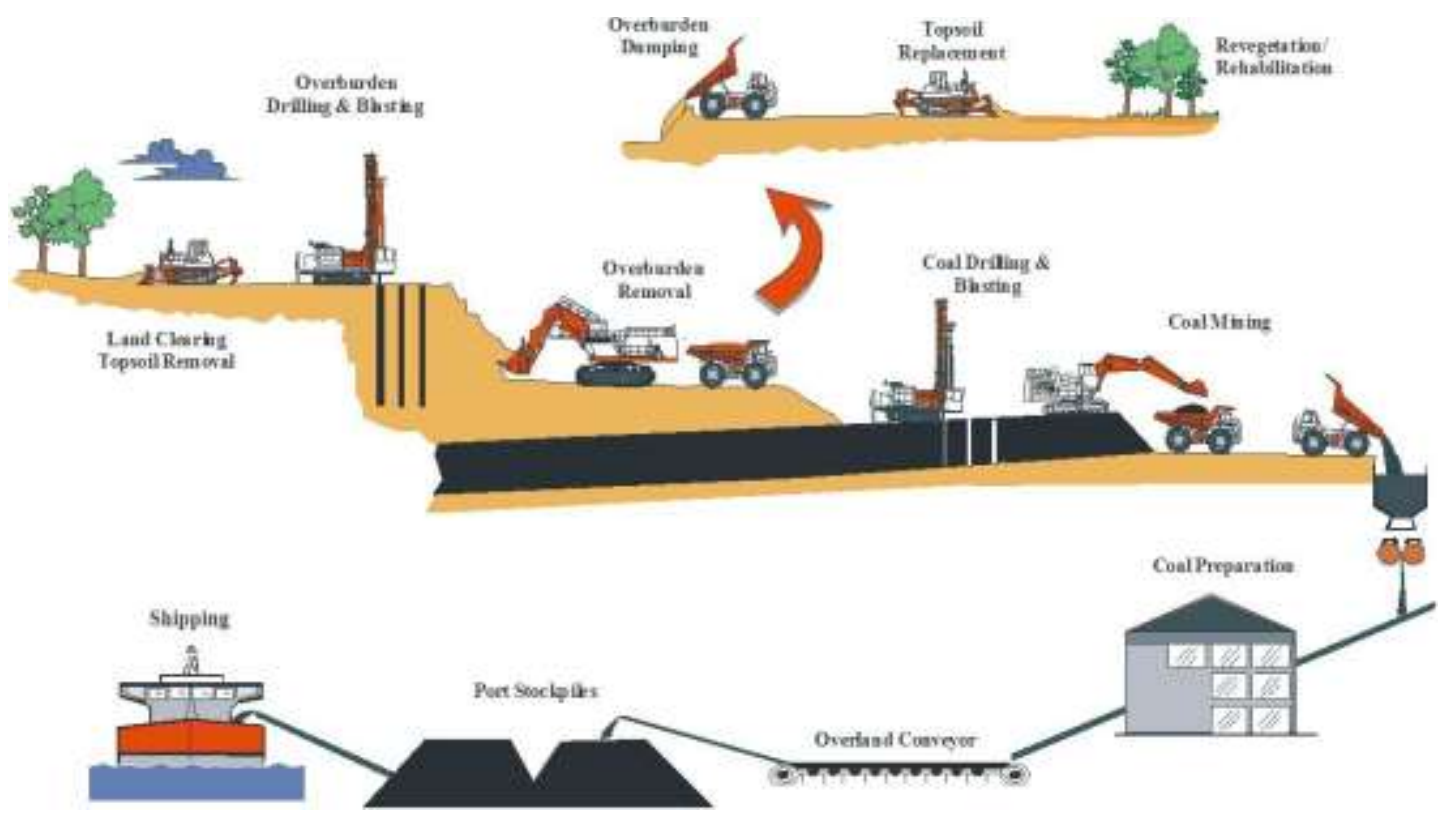

Figure 3. Open Pit Coal Mining Activities Overview

Coal mining activities are usually explained into several stages as the following. These stages and their related key acitivies shall be including exploration and feasibility stage, planning and construction phase, mining operations phase and mining closure phase.

1. The first is exploration and feasibility stage, and its key activities include investigation, discovering mineral variances, discovery, sampling, and economic feasibility study;

2. The second is planning and construction stage, and its key activities include mining planning, environmental/social planning, closure planning, environmental and other permits, clearing, blasting, and infrastructure construction. The scope and complexity of the works to be completed at this stage vary from project to project. It is undisputable that this stage needs to procure most services in the mine life cycle, including the most number of employees and contractors.
3. The third is operation stage, and its key activities include removal of overburden removal, coal getting, material trucking and conveying, ore crushing, grinding, concentrating, waste rock, tailings and wastewater management, and gradual reclamation. This stage usually will consume most available resources of the mining company;

4. The final is closure stage, and its key activities include site clean-up, reclamation, rehabilitation, maintenance, and environmental monitoring. The coal mining company's expenditure for this stage usually around $15 \%$ at minimum in the following 2 (two) years and most of coal mining company outsource this working activity.

\section{METHODOLOGY}

The research method is a process composed of stages that are systematically interrelated with one another. The research flowchart can be seen in Figure 4. 


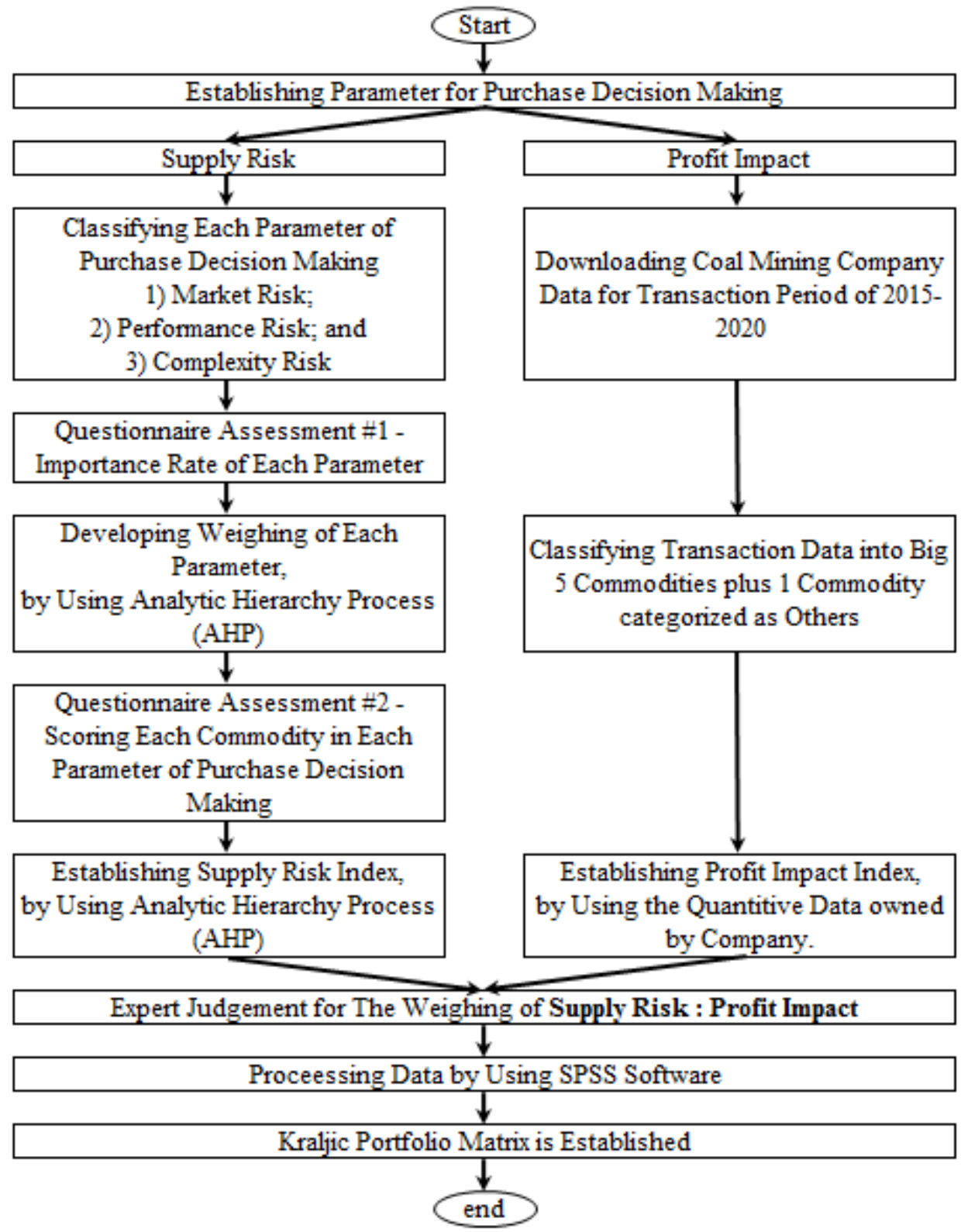

Figure 4. Flowchart of Research Methodology

As Kraljic Portfolio Matrix introduced by Kraljic (1983) categorizes procurement items based on two dimensions, namely profit impact and supply risk, hence for the first stage, the researchers categorized into two major processes which are establishment of profit impact and supply risk.

For index of supply risk, it is developed from questionnaire assessment which subsequently calculated with Analytic Hierarchy Process (AHP). While for profit impact, it is developed by using actual transaction value for period of 2015 to 2020 . At the end of processes, index of supply risk and index of profit impact is merged into Kraljic Portfolio Matrix by using SPSS software.

Details of methodology shall be read as follow.

\section{DETERMINATION OF DIMENSION AND ATTRIBUTE}

Dimensions used in this research is profit impact and supply risk. Both dimensions have been verified by Gelderman \& Van Weele (2005), Gelderman (2003), and Caniels \& Gelderman (2005). These dimensions are appropriate for application of Kraljic portfolio matrix. With reference to research by Padhi (2012), both methods are explained as the following.

\section{Profit Impact}

This dimension represents added value resulted from procurement of every raw material, not only in the production line, percentage of raw material costs in the total Cost of Goods Sold (COGS), but also the effect in the profit rate. 
With reference to the actual transaction value during 2015 to 2019 for a largest open pit coal mining company in the world, the percentage of commodities purchased is as follow.

Table 2. Purchasing Profile per Commodity for Open Pit Coal Mining Company

\begin{tabular}{|c|c|c|}
\hline No. & Commodity & Percentage \\
\hline 1 & Fuel & $70.15 \%$ \\
\hline 2 & Maintenance of Mobile Equipment & $14.91 \%$ \\
\hline 3 & Blasting Material & $7.22 \%$ \\
\hline 4 & Tyre & $4.22 \%$ \\
\hline 5 & Lubricants & $1.45 \%$ \\
\hline 6 & Others & $2.06 \%$ \\
\hline & Grand Total & $100 \%$ \\
\hline
\end{tabular}

Purchasing profile for each coal mining company may be slightly different, depends on the technical driver factors. Elisman, Ongky, and Nainggolan, Yunieta Anny (2020) advised that the technical driver factors which will involve to the purchasing profile are equipment performance (physical availability, productivity, and the fuel burned rate) and production planning (stripping ratio, hauling distance, mine area availability, and geological/planning accuracy).

Stripping ratio is the amount of waste (or overburden) that must be removed to release a given ore quantity. It is a number or ratio which expresses how much waste is mined per unit of ore.

However, even that these abovementioned technical driver factors will involve to the purchasing profile, the composition of purchasing value percentage would be similar to Table 2.

\section{Supply Risk}

This dimension represents supply risk which may occur, such as supply scarcity, substitution of raw materials, logistics costs, and market complexity supply. This dimension can be described into multiple attributes to limit and weighted, namely:

\section{Market Risk}

This attribute indicates the availability of potential supplier for each procurement item, type of market (monopoly or oligopoly), and the limitations which have to be faced when entering the supply market. Company is in opinion that market risk attribute as the availability of supply and supplier in supplying raw materials.

\section{Performance Risk}

This attribute discusses quality and performance of supplier in supplying raw materials. Company is in opinion that performance risk as supplier performance in term of delivery time and product quality.

\section{Complexity Risk}

This attribute relates to the standardization and specification of procured item. Company is in opinion that complexity risk as consideration of specification and raw material standard.

\section{DATA COLLECTION}

This research is developed with reference to the solution for supplier selection problem with AHP based introduced by Nirmala and Uthra (2019). Nirmala and Uthra (2019) introduced that the first methodology will be construction of hierarchical structure problems to be solved. Subsequently decision maker, for this research will be professional purchasers within coal mining company, to provide preference for comparison matrices with respect to goal and criteria. Then the priority vectors (factors?) are determined for all comparison matrices. Finally, all the weights from the lowest level of the hierarchy to the highest level of the hierarchy are combined, overall weights are ranked, and Kraljic Matrix is plotted based on indexes of supply risk and profit impact.

This research will have 2 (two) stages of questioner. First questioner is to assess the importance level of each attribute in the dimension of purchasing activity. Assessment will use linguistic scale at 1 to 10 (no importance to extremely importance). This questioner requires assessment from purchasing experts from internal company refer to (Padhi, 2012) which involve 11 purchasing experts working for Purchasing Department in a largest open pit coal mining company in the world.

Second questioner is to assess every commodity against each supply attribute. Assessment will use correctness scale at Correct, Doubtful and Incorrect. This questioner also requires assessment from purchasing experts from internal company refer to (Padhi, 2012) which involve 11 purchasing experts working for Purchasing Department of a largest open pit coal mining company in the world.

\section{RESULT AND ANALYSIS}

The calculations are carried out in every important level of attributes and performance value of each commodity, both in in the Analytical Hierarchy Process, also subsequently classification in the Kraljic matrix. Result of these calculations will be used as the basis in developing purchasing strategy of commodity procurement in open 
pit coal mining company.

\section{IMPORTANCE VALUE OF ATTRIBUTE}

The average importance value of each attribute which has become weighted number for the supply risk dimension is a) 3.0452 for market risk; b) 2.8695 for performance risk; and c) complexity risk resulted 3.0948.

Abovementioned values are subsequently normalized to create normalization of weighted dimension for supply risk at $32.84 \%$, for performance risk at $34.85 \%$ and for complexity risk at $32.31 \%$.

Based on discussions with company procurement experts, the weight for the supply risk dimension is $20 \%$ and $80 \%$ for profit impact. This is based on the company's tendency to consider the dominant impact of profits in carrying out procurement activities rather than considering the risk of supply.

\section{PERFORMANCE VALUE PER COMMODITY}

Performance values are assessed for each commodity based on each attribute. As the example in fuel as commodity, the market risk attribute is 2.1091 , the performance risk attribute is 1.2500 and the complexity risk attribute is 2.000 . The performance value is subsequently multiplied with weighing of each attribute and to be summed up then. As a result, the weighted average value of supply risk index for fuel is 1.5688 .

The weighted average value of supply risk index is multiplied then with the weight of supply risk dimension that was discussed earlier at $20 \%$. The final performance value of fuel for supply risk dimension is 0.36138 . Full of performance value for each commodity shall be read in Table 3.

Table 3. Performance Values of Each Commodity in Open Pit Coal Mining Company

\begin{tabular}{lcc}
\hline \multicolumn{1}{c}{ Commodity } & Supply Risk & Profit Risk \\
\cline { 2 - 3 } & Global Average & Global Average \\
\hline Fuel & 0.3138 & 0.5612 \\
Maintenance of Mobile Equip. & 0.3688 & 0.1192 \\
Blasting Material & 0.3675 & 0.0578 \\
Tyre & 0.3806 & 0.0337 \\
Lubricants & 0.3000 & 0.0116 \\
Others & 0.3191 & 0.0164 \\
\hline
\end{tabular}

\section{KRALJIC MATRIX RESULT}

Value of global average for each commodity from the two dimensions will then produce a Euclidean matrix which will be input to the Kraljic portfolio matrix through multidimensional scaling with SPSS software. The meaning of each element in the matrix represents Euclidean distance separating the two raw materials from each other.
As the example, d12 element amounting to 0.4453 is interpreted that fuel commodity separated 0.4453 points from maintenance of mobile equipment commodity. The greater Euclidean distance separates the two types of commodity, the distance in the Kraljic Portfolio Matrix will be farther. The result of Kraljic Portfolio Matrix is plotted in Figure 4.

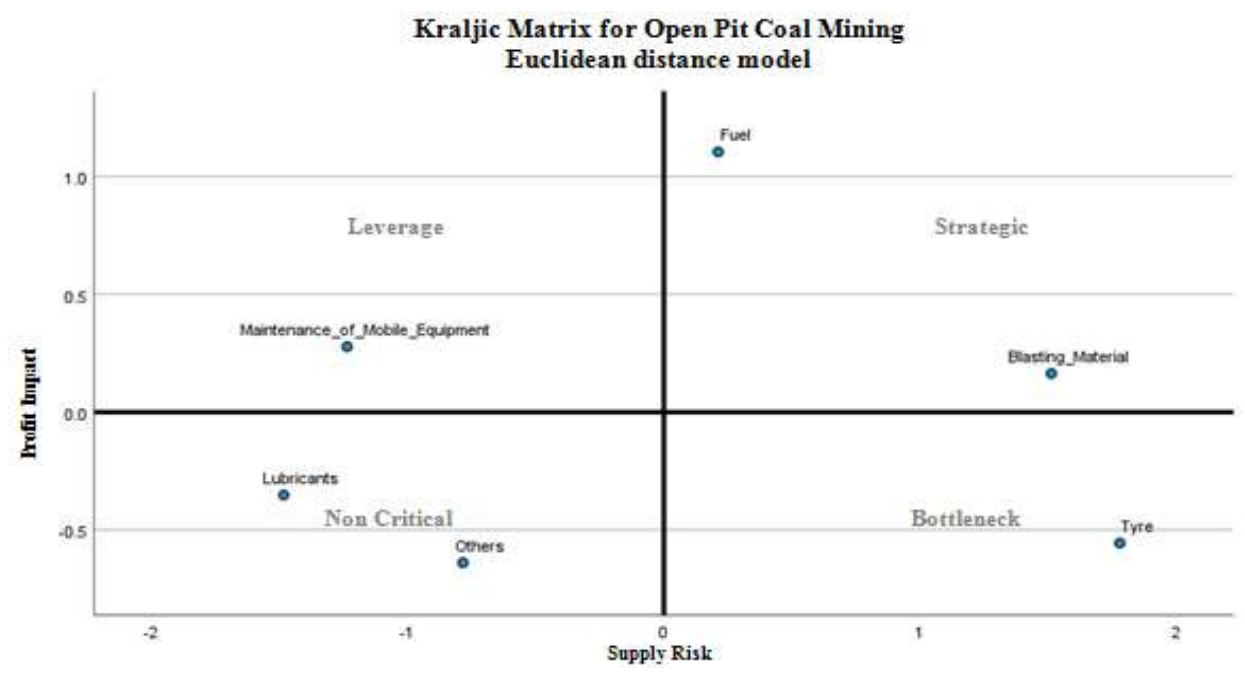

Figure 4. Kraljic Portfolio Matrix for General Open Pit Coal Mining Company 


\section{PURCHASING STRATEGIES}

\section{Non-Critical Commodity}

Main characteristics of this quadrant are low supply risk and also low profit impact. Lubricants and others are commodities which are available in the market. The Company has no concern in terms of time punctual, supply availability, also quality risk from supplier's supply, also no complexity in terms of standardization and specification of these commodities.

Profit impact to the company's efficiency is also in a low level as the transaction value is not as many as other commodities in terms of coal operations expenditure. Therefore, substitution and purchase postponement may be approached as it can be easily substituted with other products.

Recommended strategy for commodity(ies) under this non-strategic quadrant is by appointing supplier which has very efficient supply chain channel and has consolidation point close to the mining site. The company does not have to maintain relationship with a supplier in minimizing dependency. It is also recommended to regularly float the tendering process.

In addition, the company is also requested to improve its business processes such as substitution of material, or consolidation demands across divisions within the company. Example for lubricantproduct, has been implemented by several coal mining companies by changing the lubricant product with higher specification at $20 \%$ to $40 \%$-higher price than existing product, but the life time worth for extension from 500 hours to 1,000 hours or 3,000 hours to 6,000 hours.

\section{Bottleneck Commodity}

Main characteristics of this quadrant are high supply risk but have low profit impact to the company. Coal mining companies understood that demand in the world for Off The Road (OTR) Tyre with size from R49 to R63 is significantly higher than total production in the world. For the worst-case happened at that time coal mining industry was booming in 2012, the company had to indent for 12 to 18 months until receiving the tyres at its mining site.

Currently there are only 3 (three) famous brands of tyre which have reputable lifetime performance such as Bridgestone, Michelin and Goodyear. Other famous brands did not produce tyre in these sizes. Several low price tyres recently also have been produced OTR Tyre in growing counties, however this tyre has very low lifetime, does not have good endurance in coal mining implementation, as a result the total cost per hour would be higher than purchase tyre from famous brands.

Substitution products from other brands might be available; however it will increase the total operating cost for its mining activities.

Recommended strategy for commodity in this bottleneck quadrant is by appointing reputable and trusted company in maintaining its product quality and performance. The company should maintain its good relationship with supplier. In addition, coals mining companies must assign experience employees and managers in managing issues with this bottleneck supplier.

On the other hand, in operational insight, suppliers must be challenged by coal mining company to improve its product. For the case of tyre, manufacturer is requested to provide tyre with high tkph (tonne-kilometers per hour) but with high lifetime.

It is also suggested to sign long term agreement with the most trusted manufacturer, so that the high supply risk might be minimized.

On the other hand, coal mining company is recommended to build its own inventory stock by putting appropriate safety stock. As there is no alternate similar product, coal mining company must make sure that there will be no disruption because of the absence of tyre in its inventory stock.

\section{Leverage Commodity}

Main characteristics of this quadrant are low supply risk but have high profit impact to the company. Spare parts for maintenance activity of mobile equipment are the commodity under this leverage quadrant.

Currently coal mining company does not have any issue in term of availability. All authorized distributors are fully supported by the mobile equipment manufacturer. Guarantee certificate is also issued by mobile equipment manufacturer to be directly handed over to coal mining companies as its customer, guaranteeing that the spare parts will available for 20 years.

However, the profit impact to coal mining company is quite significant. As mobile equipment is the only equipment which can be operated mobile following the mining sequence, hence there is no reason to park-up this equipment as long as the operating cost and its technical performance are feasible.

Recommended strategy for commodity in this leverage quadrant is to source the spare parts as many as possible from their original manufacturers or firsthand distributors. It is common practice that mobile equipment manufacturer in mining industry does not produce all the spare parts as the part number for one equipment type varies to hundred or even thousand parts. Several spare parts production is outsourced from white brand spare parts manufacturer but it is produced with stamp of 
Original Equipment Manufacturer (OEM) brand as per order.

Coal mining company acknowledged that the best way in reducing cost impact is by way of renegotiation spare parts supply contract with the authorized distributor. However as spare parts price list has been decided by OEM, thus there will be no significant cost reduction for implementing this contract renegotiation.

In order to reduce the profit impact, purchasing of coal mining company must source the spare parts as many as possible from the original manufacturer. Several classifications of mobile equipment spare parts which may be approached for direct purchase from the original manufacturer are tyre, lubricant, bearing, undercarriage, Ground Engaging Tools, shovel bucket teeth, bolt-nut, etc.

\section{Strategic Commodity}

Main characteristics of this quadrant are not only high supply risk but also have high profit impact on the company. Fuel accounts for around $70 \%$ operational costs of coal companies. Fuel is required for generating power of many numbers of mobile equipment in mining operations. Besides that, fuel is also required for generating power of fixed plant for the case that coal mining company does not have its own mining mouth coal fired power plant.

Blasting material is also commodity in which also under strategic quadrant. There are limited blasting material manufacturers in the world produce high quality blasting material. In several countries, production and selling of blasting material are limited because of security issues in minimizing misuse. Therefore, there is disequilibrium condition in blasting material market in which demand is significantly higher than supply.

Fuel and blasting materials with acceptable condition for mining operations is difficult to be obtained in the market because of the special requirement in mining industry.

For fuel, it is required that the quality to be in the acceptable range in term of sulfur and viscosity; otherwise fuel cannot be filtered and may cause engine breakdown or the replacement cost of fuel filter will be higher than usual. For blasting materials, ANFO (Ammonium Nitrate which has been mixed with Fuel Oil) will only can be produced with a good quality Ammonium Nitrate and fuel. In the event that ANFO has bad quality, there would be fatal risk occurred for the case of misfire. Therefore in mining industry, government of mining concession as regulator commonly has established regulation for the limitation of misfire case for every blasting activity.

Profit impact on the company efficiency is high because these commodities are main requirement in mining operations. According to the transaction value, these have high purchasing value. Small efficiency in these commodities will have significant impact on the company's profit because of the huge quantity of consumption.

The purchase value for these raw materials made a very large contribution compared to other raw materials, namely $70.15 \%$ for fuel and $7.22 \%$ for blasting materials, from total procurement expenses. The possibility of substitution or delay in procurement is avoided because of the urgency of the specifications of fuel and blasting materials.

Recommended strategy for commodity in this strategic quadrant is to engage supplier increasing supply availability, increasing product quality, increasing loyalty, requesting cost saving project in the company coal mining operations, also requesting flexibility in payment term and delivery schedule. It is recommended company maintain a good relationship with its supplier(s), keep pushing supplier(s) to maintain their technical performance, and establish long term partnership supply contract. The coal mining company is also requested to provide its requirement accurately and to ensure that safety level in inventory level is fulfilled.

\section{DISCUSSION}

Montgomery et al. (2018) concluded that with the implementation of strategic sourcing through a purchasing portfolio framework, companies will have the opportunity to more aggressively leverage their purchasing power and select appropriate sourcing strategies and tactics. With Kraljic's portfolio matrix being the most widely used diagnostic and prescriptive purchasing portfolio framework, this research greatly contributes to this framework by providing a more quantitative and rigorously grounded matrix.

Kraljic Portfolio Matrix has been implemented in several industries. Lee, Dong Myung and Drake, Paul L. (2009) have researched the establishment of purchasing strategies in manufacturer industry, specifically in the elevator manufacturer in South Korea, so does Ferreira, Luis M., and Kharlamov, Alexander A. which has researched the implementation in construction industry. Many researchers have conducted a research in several industries, while there is no researchers implement Kraljic Portfolio Matrix for mining company.

Kusumawati, Agnes and Sari, Diana Puspita researched that PT PLN West Java and Yogyakarta Distributions has successfully increased its service level because of implementation of purchasing strategies established from Kraljic Portfolio Matrix. PT PLN West Java and Yogyakarta Distributions avoided stock out for several critical items because of right purchasing strategies 
implementation for its procurement activity.

This matrix provides decision maker in purchasing area an objective, quantitative approach for identifying products and services readiness for strategic sourcing initiatives.

With the right process in establishment of Kraljic Portfolio Matrix, the matrix developed in this research will recommend right strategies in each purchasing commodity to be purchased by open pit coal mining company. It will assist decision makers in quickly and easily identify the commodity to the implementation of commercial best practice purchasing strategies.

\section{CONCLUSION}

In the absence of Kraljic Portfolio Matrix study in mining industry, many professional purchasers in this industry implemented inappropriate purchasing strategies. In many cases as described above, several impacts may occur low service level because of stockout condition for critical items, implementation of dark purchasing in which caused by lack of clear procurement direction and strategy.

Through Kraljic Portfolio Matrix which has been analyzed as abovementioned, the researchers have concluded the main characteristics of raw materials including each strategic plan recommendation.

Commodities under non-critical quadrant such as lubricant and others have characteristic which available in the market at any time and do not have any sophisticated standard or specification. Bottleneck quadrant consist of tyre has characteristic which has limited supply in the market, and also have specific standard or specification. Spare parts for maintenance of mobile equipment are the commodity under leverage quadrant, in which available in the market can be easily substituted, and do not have high specification and standard. Strategic quadrant consists of fuel and blasting materials has characteristic which has limited supply in the market, has minimum standard and specification, and has high transaction value.

For purchase commodity under non-critical quadrant, it is recommended to implement regular trading, improve supply operations efficiency, explore opportunity for substitution, and has centralized procurement function to bundle the purchased quantity across divisions within the company into economic scale theory.

For purchase commodity under bottleneck quadrant, it is recommended to apply call-off contract. The company is also requested to maintain minimum stock at its site warehouse.

Commodity under leverage quadrant is recommended to apply call-off contract to exploit coal mining company's purchasing power.
For commodity under strategic quadrant, partnership contract type is recommended for implementation. It is also recommended that coal mining company should establish the replenishment system accurately and ensure that inventory should be kept available from time to time.

With the implementation of several purchasing strategies as explained abovementioned, professional purchasers within coal mining companies will achieve right purchasing result to purchase the mining operations demand at the lowest total cost of ownership and also avoid operations disturbance because of unavailability of critical parts.

\section{REFERENCES}

Bensaou, M., (1999): Portfolios of buyer-supplier relationships. Sloan Management Review 40 (4), 35-44.

Caniels, M. C., \& Gelderman, C. (2005): Purchasing Strategies in the Kraljic Matrix - A Power and Dependence Perspective. Journal of Purchasing \& Supply Management, 141-155.

Coal-Financial-Trends-ETA, http://www.carbontracker.org/wpcontent/uploads/2014/09/Coal-FinancialTrends-ETA.pdf. downloaded on April 27th, 2021.

Croom, S.R., (2000): The impact of web-based procurement on the management of operating resources supply. Journal of Supply Chain Management 36 (1), 4-13.

Dubois, A., Pedersen, A., (2002): Why relationships do not fit into purchasing portfolio models: a comparison between the portfolio and industrial network approaches. European Journal of Purchasing \& Supply Management 8, 35-42.

Dyer, J.H., Cho, D.S., Chu, W., (1998): Strategic supplier segmentation: the next 'best practice' in supply chain management. California Management Review 40 (2), 57-77.

Elliott-Shircore, T.I., Steele, P.T., (1985): Procurement positioning overview. Purchasing and Supply Management December, 23-26.

Elisman, O., Nainggolan, Y. A., (2020): Strengthen the Project Control Mechanism in Managing Coal Mining Business Risk with a Capital Budgeting Approach: Study in PT. XYZ.

Ferreira, L. M., Kharlamov, A. A., (2012): Application of Kraljic's purchasing portfolio matrix in construction industry - A case study. International Conference on Industrial Engineering and Operations Management (ICIEOM).

Gelderman, C.J., (2003): A Portfolio Approach to the Development of Differentiated Purchasing Strategies. Eindhoven University of 
Technology, Eindhoven.

Gelderman, C.J., Van Weele, A.J., (2002): Strategic direction through purchasing portfolio management: a case study. Journal of Supply Chain Management 38 (2), 30-37.

Gelderman, C.J., Van Weele, A.J., (2003): Handling measurement issues and strategic directions in Kraljic's purchasing portfolio model. Journal of Purchasing and Supply Management 9 (5-6), 207-216.

Gelderman, C.J., Van Weele, A.J., (2005): Purchasing portfolio models: a critique and update. Journal of Supply Chain Management 41 (3), 19-28.

Hadeler, B.J., Evans, J.R., (1994): Supply strategy: capturing the value. Industrial Management 36 (4), 3-4.

Kamann, D.F., Bakker, E.F., (2004): Changing supplier selection and relationship practices: a contagion process. Journal of Purchasing and Supply Management 10 (2), 55-64.

Kempeners, M., van Weele, A.J., (1997): Inkoopportfolio: Basis voor inkoopen marketingstrategie. In: Van der Hart, H.W.C., Van Weele, A.J. (Eds.), Dynamiek in Commercie"le Relaties. F\&G Publishing, Bunnik.

Kraljic, P., (1983): Purchasing must become supply management. Harvard Business Review 61 (5), 109-117.

Kusumawati, A., Sari, D. P., Positioning Analysis of Procurement Item Using Krlajic Portfolio Matrix. Case Study at PT PLN (Persero) East Java and Yogyakarta Distrbutions.

Lee, D. M., Drake, P. L. (2010): A portfolio model for component purchasing strategy and the case study of two South Korean elevator manufacturers. HAL archive-ouvertes. hal00543965.

Lilliecreutz, J., Ydreskog, L., (1999). Supplier classification as an enabler for a differentiated purchasing strategy. Global Purchasing \& Supply Chain Management 11, 66-74.

Montgomery, R. T., Ogden, J. A., Boehmke, B.C., (2018): A quantified Kraljic Portfolio Matrix: Using decision analysis for strategic purchasing. Purchasing \& Supply Chain Management 24.

Nirmala, G., Uthra, G., (2019): AHP based on Triangular Intuitionistic Fuzzy Number and its Application to Supplier Selection Problem. ScienceDirect.

Nellore, R., Soderquist, K., (2000): Portfolio approaches to procurement: analysing the missing link to specifications. Long Range Planning 33, 245267.

Olsen, R.F., Ellram, L.M., (1997): A portfolio approach to supplier relationships. Industrial Marketing Management 26 (2), 101-113.

Padhi, S. S., (2012): Positioning of commodities using the Kraljic Portfolio Matrix. Journal of Purchasing \& Supply Management, 18, 1-8. doi:10.1016/j.pursup.2011.10.001.

Runge, lan C. (lan Charles), (1952 - 1998): Mining economics and strategy. Littleton, CO: Society for Mining, Metallurgy, and Exploration. p. 188. ISBN 978-1-61344-104-6. OCLC 742590272

Saaty,T.L, (1980): "The Analytical Hierarchy Process". New York: McGraw-Hill.

Syson, R., (1992): Improving Purchase Performance. Pitman, London.

Tuten, T.L., Urban, D.J., (2001): An expanded model of business-to-business partnership formation and success. Industrial Marketing Management 30, 149-164.

Van Weele, A.J., (2000): Purchasing Management: Analysis, Planning and Practice. Chapman \& Hall, London.

Wagner, S.M., Johnson, J.L., (2004): Configuring and managing strategic supplier portfolios. Industrial Marketing Management 33 (88), 717-730.

Wynstra, J.Y.F., ten Pierick, E., (2000): Managing supplier involvement in new product development: a portfolio approach. European Journal of Purchasing \& Supply Management 6 (1), 49-57.

Zolkiewski, J., Turnbull, P., (2002): Do relationship portfolios and networks provide the key to successful relationship management? Journal of Business \& Industrial Marketing 17 (2), 575597. 
Indonesian Mining Professionals Journal Volume 3, Nomor 1, April 2021 : 45 - 58 